INDEPENDENT JOURNAL OF MANAGEMENT \& PRODUCTION (IJM\&P)

http://www.ijmp.jor.br

v. 11, n. 6, September - October 2020

ISSN: 2236-269X

DOI: 10.14807/ijmp.v11i6.1033

\title{
ENVIRONMENTAL COMPLIANCE AND THE LEVEL OF COMPETITIVENESS OF TILAPIA PRODUCERS INSTALLED IN HYDROELECTRIC POWER PLANTS
}

\author{
Raiane Real Martinelli \\ Universidade Estadual de Maringá (UEM), Brazil \\ E-mail: raiane.rm@hotmail.com
}

Gessuir Pigatto

São Paulo State University (UNESP), Brazil

E-mail: gessuir.pigatto@unesp.br

Timoteo Ramos Queiroz

São Paulo State University (UNESP), Brazil

E-mail: timoteo.queiroz@unesp.br

Ferenc Istvan Bánkuti

Universidade Estadual de Maringá (UEM), Brazil

E-mail: ferencistvan@gmail.com

Submission: $4 / 3 / 2019$

Revision: 9/18/2019

Accept: 10/22/2019

\section{ABSTRACT}

Aquaculture is one of the fastest-growing food sectors in Brazil. Cage fish farming has been widely practiced in the country, mainly in hydroelectric reservoirs. However, different regulatory, technical, and economic challenges may need to be overcome before the sector can achieve increased national and international competitiveness. This study aimed to analyze and compare the competitiveness of tilapia cage farms located on different sides of the Canoas I hydroelectric reservoir, which forms the border between the states of São Paulo and Paraná, Brazil. Structured questionnaires were administered to all fish farmers in the reservoir. Questions about seven competitiveness indicators were rated on a 5-point Likert scale. The results revealed that the major barriers to competitiveness are the institutional environment and environmental sustainability. Paraná has an active environmental inspection service, but São Paulo does not. As a result, tilapia fish farmers in Paraná gave more importance to environmental compliance than those located in São Paulo. 
DOI: 10.14807/ijmp.v11i6.1033

Keywords: institutional environment; competitiveness; fish farming; environmental sustainability; net cage systems

\section{INTRODUCTION}

Fish is part of the cultural and gastronomic heritage of many peoples. As a food product, fish is an important source of protein, fatty acids, vitamins, minerals, and essential micronutrients. Global fish consumption has grown significantly over the years. In Brazil, the average consumption of seafood was $11.2 \mathrm{~kg}$ per capita in 2011, 14.5\% higher than that in 2010 (BRASIL, 2013). Brazilian fish production grew by about 8\% per year from 2004 to 2014, representing the largest growth rate in the national meat market, surpassing that of poultry (4.1\%), cattle (5.1\%), and pig (2.9\%) farming (KUBITZA, 2015).

Fish farming is the major aquaculture activity, corresponding to $86.6 \%$ of the national aquaculture production (BRASIL, 2012). Net-cage fish farming has grown rapidly in recent years. Cage fish farms can be installed in natural aquatic environments at low costs and be easily expanded. Net cages facilitate fish handling, feeding, and harvesting (ONO; KUBITZA, 2003; SANDOVAL Jr. et al., 2013).

Nile tilapia (Oreochromis niloticus) is widely produced in net cages. This species has important characteristics for cage production, such as rusticity (disease resistance and adaptation to intensive cultivation) and good performance (high feed conversion rate and yearround production) (AYROZA et al., 2005; SANDOVAL Jr. et al., 2013).

Water reservoirs used for water supply, electricity generation, and irrigation can also be used for cage fish farming (SAMPAIO; BRAGA, 2006; AYROZA; AYROZA, 2012). The state of São Paulo has 18 hydroelectric reservoirs, which occupy an area of 1 million ha. The reservoir of the Canoas I hydroelectric power plant has a total area of $30.85 \mathrm{~km}^{2}$ and is located on the Paranapanema River between the municipalities of Cândido Mota, state of São Paulo, and Itambaracá, state of Paraná (DUKE ENERGY, 2013).

Fish farming in Brazil is transitioning from low-tech, subsistence systems to large-scale, commercial systems (OSTRENSKY et al., 2008). However, some regulatory, technical, and economic factors have acted as obstacles to a quick and efficient transition (SIDONIO et al., 2012). The organizational arrangements of the fish industry are very diverse and lack coordination (BARROS et al., 2012). 
DOI: 10.14807/ijmp.v11i6.1033

The aim of this study was to analyze the competitiveness of net-cage fisheries located in the Canoas I hydroelectric reservoir and compare the differences between fish farms in São Paulo and Paraná.

\section{COMPETITIVENESS}

In the current context of globalization, competitiveness constitutes an important factor for economic success, one that is often advocated by economic policymakers worldwide (PÉREZ-MORENO et al., 2016). Private companies from diverse economic sectors actively pursue a leadership position to thrive in increasingly consolidated markets.

However, despite its importance for economic actors, competitiveness does not have a clear and generally accepted definition. This hinders the development of appropriate methodologies to analyze competitiveness and identify the major factors affecting it. The multiplicity and diversity of variables that influence competitiveness explain why this concept has various definitions and is associated with different indicators. Competitiveness embeds different ambiguities and difficulties (BUCKLEY et al., 1988; AJITABH; MOMAYA, 2003; HERCIU; OGREAN, 2015).

Before conceptualizing the term competitiveness, we must first define the environment in which it is to be analyzed. Competitiveness can be analyzed at the level of countries, regions, sectors or productive chains, organizations, and products. Research carried out by Ajitabh and Momaya (2003) and Balkyte and Tvaronaviciene (2010) and corroborated by Herciu and Ogrean (2015) identified three perspectives with greater recurrence: national, sectorial, and organizational competitiveness. Production factors and technology are the basis for establishing competitive conditions for an organization, a product, or a productive sector. According to Chikan (2008), Kinra and Antai (2010), and Cetindamar and Kilitcioglu (2013), the competitiveness of organizations and nations cannot be determined from an isolated perspective; it is necessary to consider both institutional and organizational factors because macroeconomic conditions influence the microeconomic environment and vice versa.

The competitiveness of a product is based on its price and differentiation and depends on the company's use of available resources and competitiveness at the organizational level (CHANG MOON; PERRY Jr., 1995). Within the microeconomic environment of a company, competitiveness is associated with the relationship between the company's goals for production and/or sale and that of its competitor (CHUDNOVSKY; PORTA, 1990). Wood Jr and Caldas (2007) defined competitiveness as the ability of a system (country, sector, company or group of companies) to operate successfully in a particular business context. Overall, competitiveness 


\section{INDEPENDENT JOURNAL OF MANAGEMENT \& PRODUCTION (IJM\&P)}

http://www.ijmp.jor.br

v. 11, n. 6, September - October 2020

ISSN: 2236-269X

DOI: 10.14807/ijmp.v11i6.1033

can be viewed as the ability of an actor to respond better than its competitors to the demands of the consumer market.

Although the economic environments evaluated in competitive analysis differ greatly from one another, they are closely related. For instance, Chikán (2008) pointed out that a country cannot be competitive if its economic agents and sectors are not. On the other hand, the competitiveness of companies is directly affected by government decisions and actions. According to Farina (1999), vertical coordination may represent a major bottleneck. The competitiveness of countries depends on political, social, cultural, and economic characteristics that influence not only the life quality of citizens but also company performance (PORTER et al., 2007).

Sustainable competitiveness has gained recent attention in competitive analysis. It involves institutions, policies, and other factors that make a nation productive in the long term while ensuring social and environmental sustainability (BILBAO-OSORIO et al., 2013; BILBAO-OSORIO et al., 2014). Whereas competitiveness is related to productivity, sustainable competitiveness is associated with aspects that go beyond immediate economic results, such as long-term economic growth and population and environmental wellbeing (BILBAO-OSORIO et al., 2013; BILBAO-OSORIO et al., 2014). Balkyte and Tvaronavičienè (2010) defined sustainable competitiveness as the balance between economic, social, and environmental development. Such balance is essential in the current scenario of globalization and economic dynamism.

Buckley et al. (1988) and Man et al. (2002) argued that competitive analysis must include the performance and competitive potential of the actor and the process, as managerial decision making affects competitive potential. Man et al. (2002) proposed four characteristics for competitiveness: relativity, as comparisons are needed; long-term orientation; dynamism, to transform competitive potential into results; and controllability, as a company should be able to control resources and capacities to achieve superior performance.

Companies must be able to change the characteristics of the competitive environment, such as competition standards and the market structure (BEST, 1990). This intervention capacity is extremely valuable in the food production chain, in which strategic actions can create new markets and change existing ones (FARINA, 1999).

The competitive performance of an organization is affected by (i) internal factors, such as technological and productive capacity, human resources, market knowledge, and relationship with suppliers; (ii) structural factors, such as consumer market and competition, over which the organization does not have full control; and (iii) systemic factors, such as 
DOI: 10.14807/ijmp.v11i6.1033

macroeconomic, political, institutional, regulatory, structural, infrastructural, and social factors, which are external to the organization but directly affect it (COUTINHO; FERRAZ, 2002; LATRUFFE, 2010).

According to Buckley et al. (1988), individual measures of competitiveness do not capture the full essence of the concept. Competitive analysis should take into account the level (nation, sector, company, or product) and competitive performance, sustainability, and management.

The set of factors influencing competitiveness can be viewed as drivers of competitiveness. They must be able to reflect the aspects that determine the cause of competitiveness of a given environment (MARTIN et al., 1991). Competitiveness drivers generally include variables that cannot be measured directly (CAESAR; BATTLE, 2011). Indicators of competitiveness may be used to capture the various components of the concept. Indicators measure the competitive performance of a company by analyzing its productivity, technology, market share, range, product differentiation, price, costs, and customer satisfaction, among others (SIUDEK; ZAWOJSKA, 2014).

Figure 1 summarizes the concept of competitiveness and the theoretical references that permeate this work.

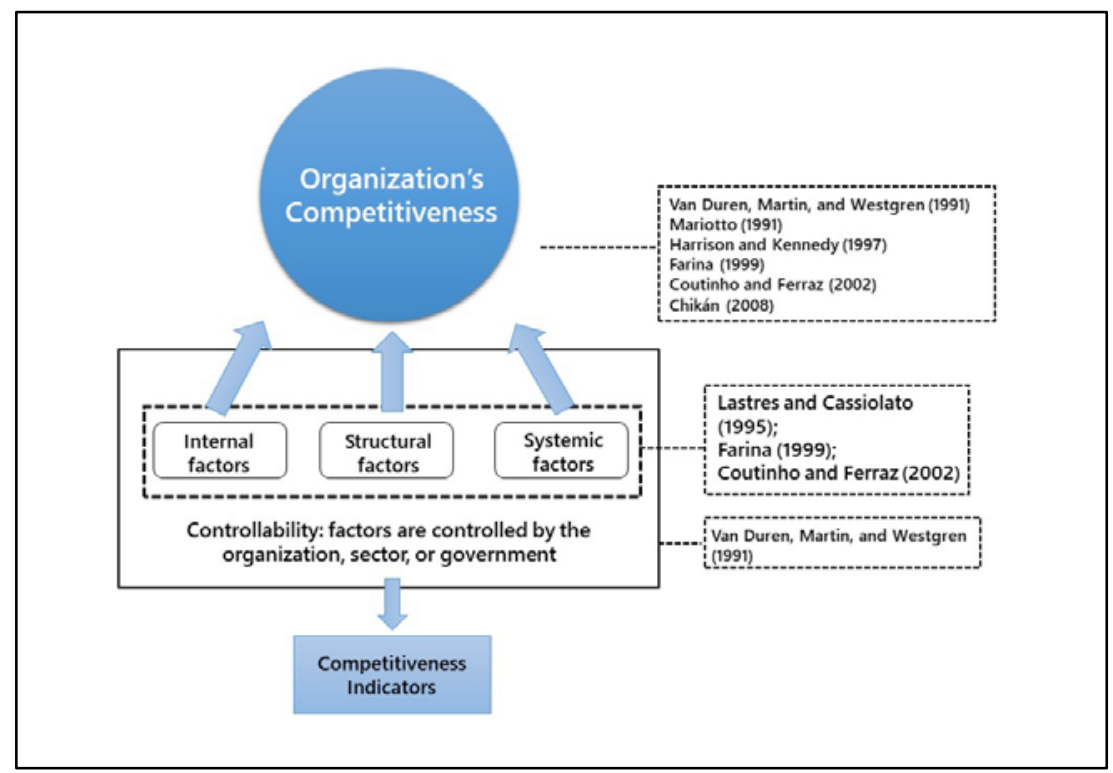

Figure 1: Factors affecting the competitiveness of an organization, according to the literature Source: prepared by the authors

The lack of consensus on the definition of competitiveness and on how to measure it does not prevent the growth and development of organizations, sectors, regions, and countries. In order to meet the objective proposed in this study, we adopt the concepts developed by Martin et al. (1991), Ferraz et al. (1995), and Farina (1999): competitiveness is the ability of 
DOI: 10.14807/ijmp.v11i6.1033

an organization to survive, and preferably expand, in a sustainable manner and maintain position in the current or in new markets. The traditional approach to competitiveness (that is, to expand market share) has changed because of the shifting nature of sources of efficiency and market structure (DIAZ-CHAO et al., 2016).

We applied the concept of organizational competitiveness to tilapia farms located in the Canoas I hydroelectric reservoir. Although farmers are not part of a formal association, their competitiveness as (an informal) group depends on the individual competitiveness of each farmer, just as the competitiveness of a country depends on the individual competitiveness of its sectors and organizations (HARRISON; KENNEDY, 1997).

Economic actors that are part of a formal group interact with other members, thereby gaining information, which can lead to innovations (GIULIANI, 2013). The evaluated fish farmers, however, are not exposed to these beneficial interactions, as they do not participate in organized groups.

\section{MATERIALS AND METHODS}

This exploratory research carried out a qualitative analysis of the case of tilapia fish farms located in the Canoas I reservoir. Data were collected using a semi-structured questionnaire.

The São Paulo Agency for Agribusiness Technology (APTA) and the Paraná Institute of Technical Assistance and Rural Extension (EMATER) provided information on the net-cage fish farmers of the Canoas I reservoir. A total of 12 fish farmers act in the reservoir, four in Cândido Mota, São Paulo, and eight in Itambaracá, Paraná.

Competitive analysis was carried out using the competitiveness drivers developed by Van Duren et al. (1991) and adapted by Silva and Batalha (2000). Batalha and Souza Filho (2009), in a study about the competitiveness of Mercosur agribusinesses, highlighted the importance of competitiveness potential-the organization's ability to convert inputs into products, thereby improving its performance. Competitiveness potential, considered an ex ante phenomenon, is related to factors that boost the competitive position of an organization (FERRAZ et al., 1995).

In general, studies on competitiveness potential use comparative analysis to evaluate the different facets of competitiveness. Martin et al. (1991) analyzed the competitiveness of Canadian agribusinesses by comparing drivers of competitiveness. Silva and Batalha (2000) adapted Martin's comparison model to analyze the competitiveness of Brazilian beef 
DOI: 10.14807/ijmp.v11i6.1033

production systems. Batalha and Souza Filho (2009) used this theoretical framework in their analysis of the competitiveness of Mercosur agribusinesses.

Key performance indicators for measuring competitiveness have been developed on the basis of quantitative and qualitative information. The main competitiveness drivers, as discussed by Van Duren et al. (1991) and Silva and Batalha (2000), are technology and innovation, inputs and infrastructure, market structure, internal management, institutional environment, and market relations. In the paragraphs that follow, we provide a detailed presentation of each driver.

Technology and innovation are related to business decisions. They have a direct influence on productivity, product cost, and product quality and allow companies to differentiate their products and define their production costs. Technology is controlled by the organization. However, agricultural organizations generally depend on other agents for the development of new technologies. The characteristics of the sector and the organization influence the decisions of technology adoption. This factor is controlled by the organization and depends on the interest and financial conditions for acquiring available technologies. In this study, three sub factors compose this driver: net cages, equipment, and formulated feed.

Inputs and infrastructure are characterized by the supply rate, quality, quantity, and price of inputs. They affect the organization's ability to maintain or increase its market share and, consequently, its competitiveness. The organization does not have complete control over this driver and is generally dependent on other economic actors, including the public sector. Input and infrastructure sub factors are (i) feed quality and distance from feed suppliers availability and quality of inputs, (ii) fingerling quality and distance from fingerling suppliers, (iii) road and traffic conditions, and (iv) infrastructure.

Market structure is extremely important, as the competitiveness of organizations depends directly on their level of market participation. The sub factors distance from main customers, number of fish farmers in the reservoir, ability to negotiate with buyers, ability to negotiate with suppliers, production capacity in relation to market size are used to evaluate this driver.

Internal management is a driver controlled solely by the organization. It is related to the use of tools that allow the manager to identify and understand the market situation and apply his/her resources in the best way possible. The analyzed sub factors are labor quality and management of fish cages and equipment.

Institutional environment, or government actions, has a strong influence on the competitiveness of companies. They are systemic factors not controllable by the organization. 


\section{INDEPENDENT JOURNAL OF MANAGEMENT \& PRODUCTION (IJM\&P)}

http://www.ijmp.jor.br

v. 11, n. 6, September - October 2020

ISSN: 2236-269X

DOI: 10.14807/ijmp.v11i6.1033

The sub factors are federal legislation, state legislation, government incentives, access to subsidized credit, and impact of environmental legislation.

The driver market relations reflects how agents interact with the market. The sub factors relationship with buyers, pricing and payment methods, formal contracts with buyers, and incentives for partnership or joint actions with other farmers or buyers are assessed.

The present research analyzes agents of the fish industry who use water resources and are generally located in river or flooded areas. Therefore, a seventh driver of competitiveness was proposed: environmental sustainability. This driver is composed of the following sub factors: compliance with environmental legislation, positive and negative environmental impacts of the fish farm, and positive and negative environmental impacts of fish farming. To meet national and international demands, several countries have continuously developed and improved management technologies. This environmental indicator is important, as it can be used to help farmers achieve increased production volumes and efficiency gains in a limited natural resource (RANA; HASAN, 2013). With the development and intensification of aquaculture, the need to monitor water resources increases (SAMPAIO et al., 2013). According to Barbosa and Candido (2013), environmental regulations, company reputation, and consumer awareness are factors that contribute to the degree of environmental compliance of an organization.

Respondents were asked to rate, on a 5-point Likert scale, how favorable or unfavorable each sub factor was for competitiveness. The scale ranged from "very favorable" to “favorable,” “neutral,” “unfavorable,” and “very unfavorable” (Table 1S, Supplementary Material). Answers were converted to values (varying from -2 for "very unfavorable" to +2 for "very favorable”). Means $(n=12)$ were calculated for each sub factor. Because competitiveness drivers differ in their number of sub factors (for example, internal management contains two sub factors and market structure contains five), each sub factor was normalized so that the sum of all sub factors within a driver equaled 1 . Subsequently, the weight of the sub factor was multiplied by its score. The weighted driver score was calculated by the sum of its weighted sub factor scores. The same procedure was used to calculate the score of each sub factor and driver by state, except that data were used according to the location of the fish farm ( $n=4$ for São Paulo and $n=8$ for Paraná).

\section{RESULTS AND DISCUSSION}

The sample included farmers who had little experience with fish culture (less than one year) as well as more experienced farmers (>10 years of farming) (Figure 2). 
DOI: 10.14807/ijmp.v11i6.1033

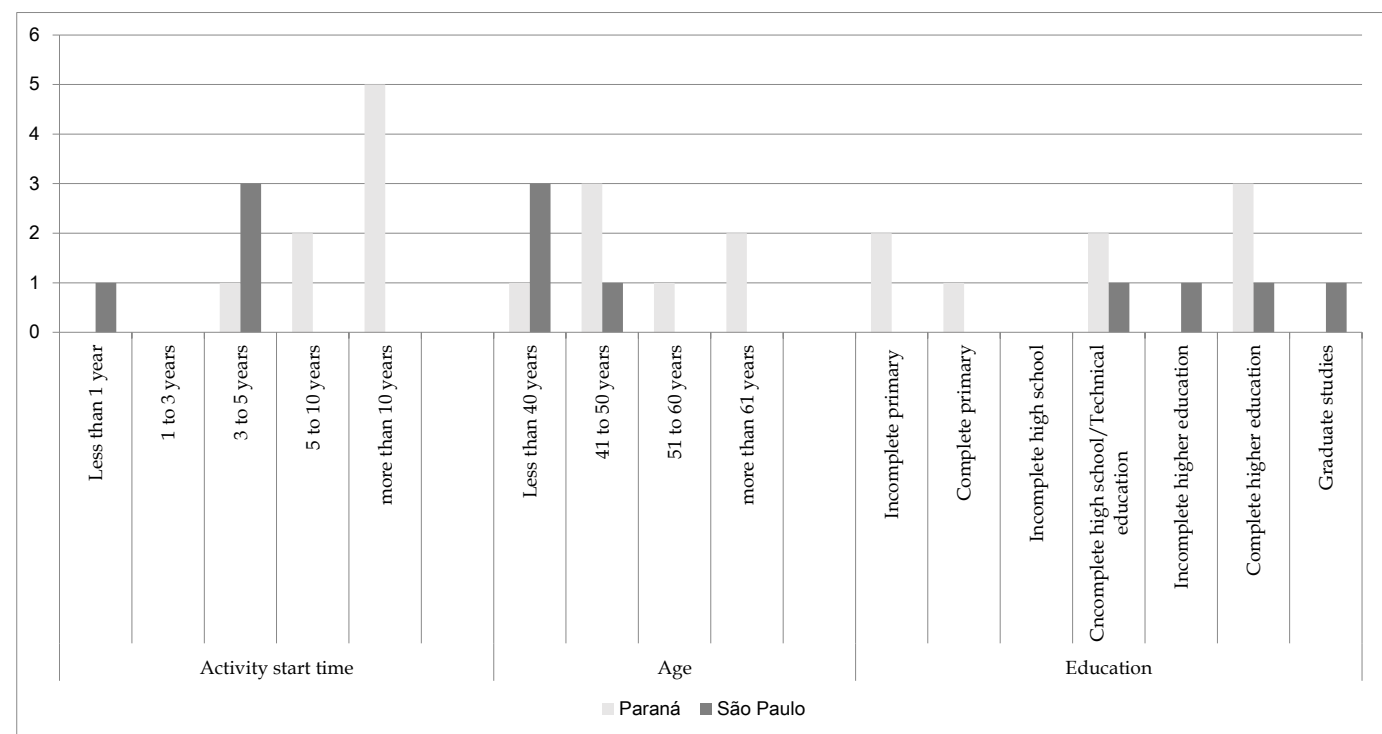

Figure 2: Distribution of tilapia fish farmers according to their farming experience, age, and level of education Source: prepared by the authors.

Most fish farmers in São Paulo are young ( $<40$ years), have few years of farming experience ( $<5$ years), and completed at least a high school degree. Fish farmers in Paraná, on the other hand, are older, more experienced, and have lower levels of education. Of the 12 farmers interviewed, 10 reported that tilapia cultivation was their main source of income.

Figure 3 shows the perception of fish farmers about whether technology and innovation, inputs and infrastructure, market structure, internal management, institutional environment, market relations, and environmental sustainability are favorable or unfavorable factors for competitiveness.

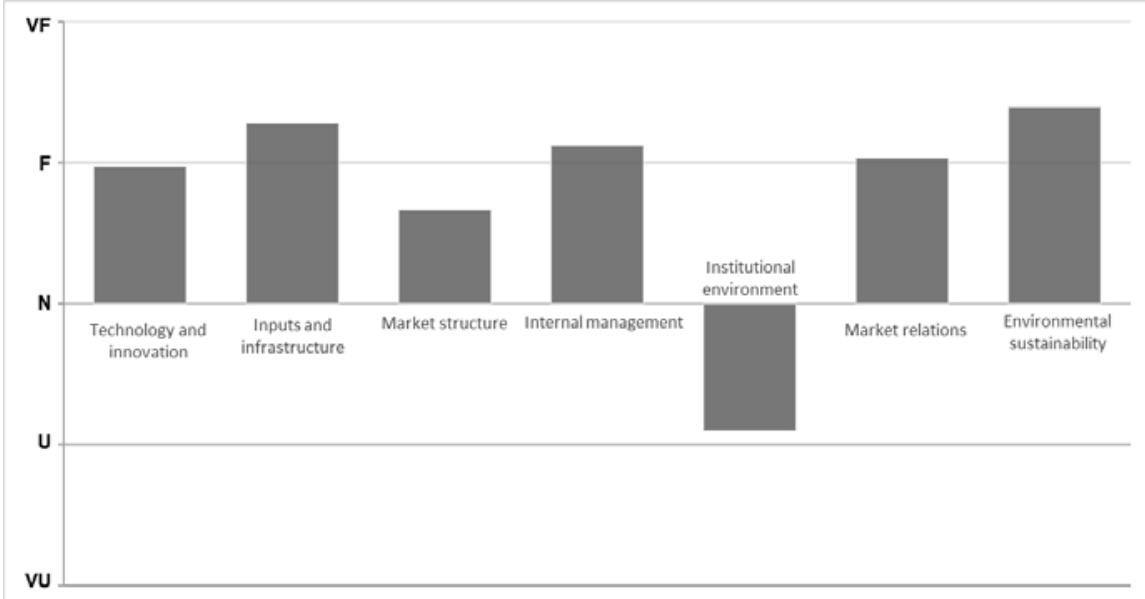

Figure 3: Drivers of competitiveness as perceived by tilapia fish farmers in the Canoas I hydroelectric reservoir.

VF, very favorable; F, favorable; N, neutral; U, unfavorable; VU, very unfavorable Source: prepared by the authors 
DOI: 10.14807/ijmp.v11i6.1033

All farmers regarded technology and innovation as favorable to the competitiveness of net-cage tilapia production in the Canoas I reservoir. The level of technological development was satisfactory in all farms, and no "technological gap" was observed. Fish farming with net cages is simple and low cost, so it is not difficult for farmers to adopt new technologies. The results indicate that the analyzed fish farms do not require large investments in technological innovation. Only one farmer (São Paulo) regarded the net cages as unfavorable for competitiveness. For all other farmers, net cages are favorable or very favorable factors.

Inputs and infrastructure were reported to have a favorable or very favorable impact on competitiveness, but inputs sub factors received a much higher score than infrastructure sub factors. Specialized companies provide a reliable supply of high-quality feed and fingerlings, thereby stimulating fish farming in the region. On the other hand, road conditions and transportation may be a bottleneck to competitiveness. The respondents stated that municipal and federal roads are in poor condition. Unfortunately, farmers do not have control over this situation and are negatively affected by the lack of public investment in infrastructure. Asphalt recapping could improve the flow of inputs to the farms and the flow of products to the market. Collective efforts are needed to attract the attention of the public sector to this problem.

The impact of market structure on competitiveness was considered neutral to favorable. In particular, the relationship between production capacity and market size was regarded as an unfavorable or very unfavorable factor. This result can be explained by the fact that there is a high local demand for tilapia but the productivity is low. Although there is no more room for the establishment of new fish farms in the Canoas I reservoir (no available concessions), farmers can improve productivity by increasing the number of fish cages in their property. However, financial constraints limit the expansion of aquaculture production. Farmers reported that the institutional environment creates unfavorable or very unfavorable conditions for competitiveness, as they have little access to subsidized credit and there are no government incentive programs. These two sub factors received the lowest scores, mainly by São Paulo farmers.

The number of fish farmers in the reservoir and their ability to negotiate with buyers and suppliers were considered very favorable factors for competitiveness. The short distance from the main customers was regarded as favorable. Respondents stated that most buyers, which included middlemen, processing companies, fishing ponds, and eateries, were located within $200 \mathrm{~km}$ of the reservoir.

Internal management was defined as having a favorable impact on competitiveness, but some farmers experienced problems in finding skilled labor. Management of cages and 
DOI: 10.14807/ijmp.v11i6.1033

equipment was regarded as favorable or very favorable. Fish farmers used at least one of the following management tools: information technology, production planning, cost control, or revenue control.

The institutional environment was identified as unfavorable for the competitiveness of net-cage tilapia production. Regulatory agencies require extensive paperwork and take large amounts of time to issue concession permits and environmental licenses for aquaculture. Some requests have remained unanswered for more than 10 years. Frequent processual, bureaucratic, and organizational changes contribute to the unfavorable impact of the institutional environment on fish farming competitiveness.

The interviewees complained specifically about environmental inspection. Even though they are located in the same reservoir, farms in São Paulo and in Paraná are monitored by different inspection services ${ }^{1}$. In Brazil, authorization for use of reservoir waters is granted by federal agencies, whereas environmental licensing and monitoring are the responsibility of state agencies, which often have different procedures and requirements.

Market relations were viewed as favorable, as most interviewees indicated they had a positive relationship with buyers and applied mutually beneficial pricing and payment strategies.

Tilapia farmers in São Paulo and Paraná differed in their views about the competitiveness impacts of environmental sustainability. Nevertheless, most interviewees recognized the importance of environmental compliance.

Competitiveness indicators were also evaluated by state, as shown in Figure 4.

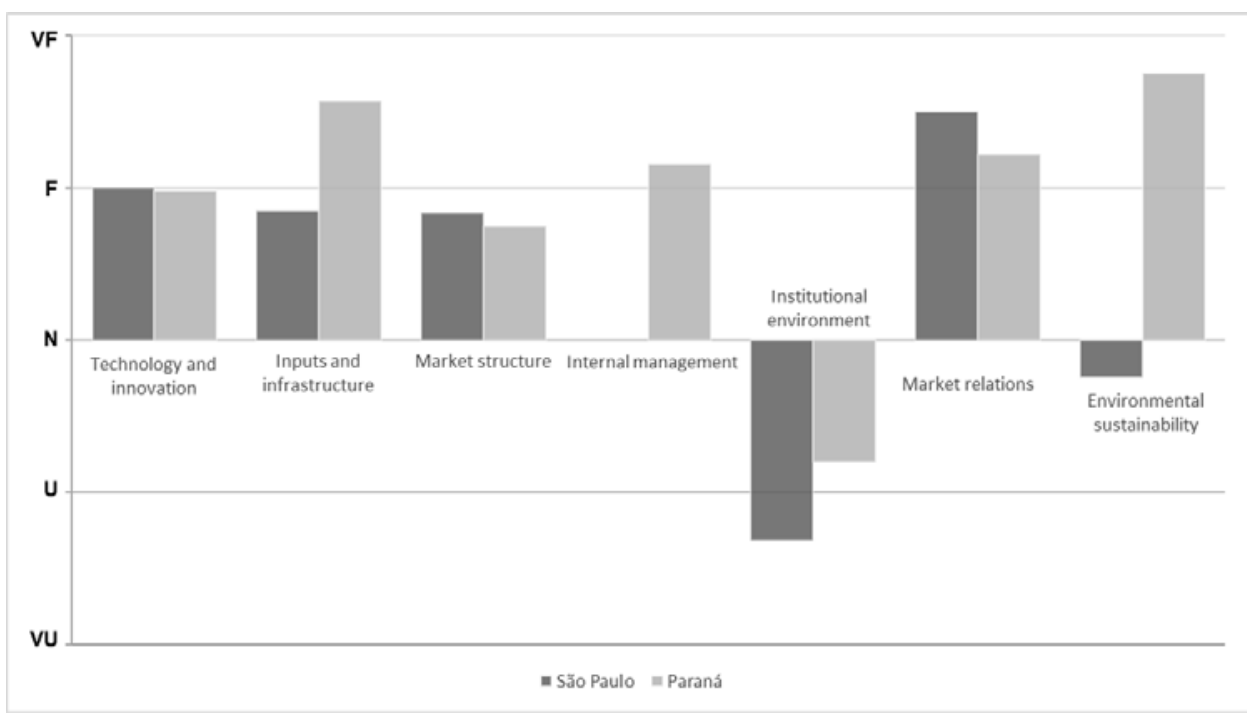

${ }^{1}$ Fish farms in São Paulo are monitored by the Environmental Company of the State of São Paulo (CETESB) and those in Paraná by the Paraná Environmental Institute (IAP). 
DOI: 10.14807/ijmp.v11i6.1033

Figure 4: Drivers of competitiveness as perceived by tilapia fish farmers in São Paulo and Paraná, Brazil.

VF, very favorable; F, favorable; N, neutral; U, unfavorable; VU, very unfavorable Source: prepared by the authors

Market structure and technology and innovation were considered favorable for competitiveness by farmers in both states.

Inputs and infrastructure were considered neutral and favorable by São Paulo farmers and very favorable by Paraná farmers. São Paulo fish farmers gave a lower score to the sub factor infrastructure than Paraná farmers.

Whereas Paraná farmers believed that internal management was favorable for competitiveness, São Paulo farmers believed that this driver was neutral. São Paulo farmers reported that they had difficulties in finding skilled labor. It is possible that the many years of experience of Paraná farmers allowed them to perceive management and internal organization as key factors for competitiveness.

In Paraná, the institutional environment was considered to be neutral to unfavorable, and in São Paulo unfavorable to very unfavorable. When asked about federal and state legislation, São Paulo fish farmers considered this sub factor as an obstacle to competitiveness but Paraná farmers had neutral opinions.

The impact of market relations differed slightly between states. São Paulo farmers were less satisfied with how prices and payments are set.

The largest discrepancy was observed in environmental sustainability. The driver was rated as neutral to unfavorable in São Paulo and very favorable in Paraná. The sub factor compliance with environmental legislation was responsible for this difference. Fish farmers in Paraná believed that this sub factor was very important because of the continuous monitoring carried out by the state agency. Fish farmers must pay fines if they do not comply with environmental legislation, negatively affecting their competitiveness and market access. In São Paulo, on the other hand, fish farms are not monitored for environmental compliance. Thus, farmers believe that this sub factor does not affect their competitiveness.

\section{FINAL CONSIDERATIONS}

This study used a theoretical model for analyzing the competitiveness of net-cage tilapia production in the Canoas I reservoir. The model was initially composed of six drivers of competitiveness, namely, technology and innovation, inputs and infrastructure, market structure, internal management, institutional environment, and market relations. A seventh 
DOI: 10.14807/ijmp.v11i6.1033

driver, environmental sustainability, was added to the analysis to measure the impact of sustainable use of natural resources and environmental legislation.

The results showed that technology and innovation, inputs and infrastructure, market structure, internal management, and environmental sustainability positively affect the competitiveness of tilapia fish farms. On the other hand, the institutional environment, characterized by extensive paperwork, lack of government incentives, and difficult access to subsidized credit, is an unfavorable factor for competitiveness.

Fish farmers in Paraná and São Paulo had divergent opinions about the influence of environmental sustainability on competitiveness because environmental compliance is routinely monitored in the former but not in the latter. As a result, Paraná fish farmers acknowledged the importance of environmental sustainability for competitiveness.

This study makes two main contributions. The first is a regional analysis of net-cage fish farming, a rapidly expanding industry in Brazil. The second is a methodological contribution to competitiveness research by analyzing environmental competitiveness. Despite the importance of environmental sustainability for consumers, business partners, and the government, few studies investigate the impacts of environmental indicators on competitiveness. Thus, we hope that the methodological approach used in this study can serve as a basis for future studies and can pave the way for competitive analyses in other sectors.

A limitation of this study is that we did not interview agents upstream or downstream of the fish farms, which precludes a thorough analysis of market structure and market relations from other perspectives.

As recommendations for future studies, we suggest (i) a new analysis of fish farming competitiveness in the same region to investigate temporal trends and determine the effects of the current economic crisis on the sector and (ii) a more thorough study of competitiveness with upstream and downstream economic agents.

\section{ACKNOWLEDGEMENTS}

This study was supported by the São Paulo State Research Foundation (FAPESP, grant no. 2014/16075-2). The opinions, hypotheses, conclusions, and recommendations expressed in this study are the responsibility of the authors and do not necessarily represent the opinions of the funding agency.

\section{REFERENCES}

AJITABH, A.; MOMAYA, K. S. (2003) Competitiveness of firms: review of theory, frameworks and models. Singapore Management Review, v. 26, n. 1, p. 45-61 
AYROZA, L. M. S.; AYROZA, D. M. M. R. (2012) Panorama da Piscicultura no Estado de São Paulo. Pesquisa e Tecnologia. Apta Regional, v. 9, n. 2.

AYROZA, L. M. S.; FURLANETO, F. P. B.; AYROZA, D.; SUSSEL, F. R. (2005) Piscicultura no Médio Paranapanema: situação e perspectivas. Pesquisa e Tecnologia. Apta Regional, V. 2, n. 2.

BALKYTE, A.; TVARONAVICIENE, M. (2010) Perception of competitiveness in the context of sustainable development: Facets of sustainable competitiveness. Journal of Business Economics and Management, v. 11, n. 2, p. 341-365.

BARBOSA, M. F. N.; CÂNDIDO, G. A. (2013) Práticas ambientais e suas relações com a competitividade e a sustentabilidade: um estudo de caso em empresa agroindustrial. Latin American Journal of Business Management, v. 4, n. 2, p. 58-80.

BARROS, A. F.; BÁNKUTI, F. I.; MARTINS, M. I. E. G. (2012) Arranjos Organizacionais da Piscicultura na Baixada Cuiabana, Estado de Mato Grosso. Informações Econômicas, v. 42, n. 6.

BEST, M. (1990) The New Competition: Institutions of Industrial Restructuring. Cambridge: Harvard University Press, 296p.

BILBAO-OSORIO, B.; BLANKE, J.; CAMPANELLA, E.; CROTTI, R.; DRZENIEKHANOUZ, M.; SERIN, C. (2014) Assessing the sustainable competitiveness of nations. World Economic Forum. The Global Competitiveness Report, p. 53-82. Available: <http://www3.weforum.org/docs/GCR2013-14/GCR_Chapter1.2_2013-14.pdf>. (accessed 03 Febreary. 2016).

BRASIL. Ministério da Pesca e Aquicultura (2012) Boletim estatístico da pesca e aquicultura - Brasil 2010. Brasília. Available:

<http://www.uesc.br/cursos/pos_graduacao/mestrado/animal/bibliografia2013/luis_art4_ro usseff.pdf $>$. (accessed 28 May. 2014).

BRASIL. Ministério da Pesca e Aquicultura (2013). Consumo de pescado no Brasil aumenta 23,7\% em dois anos. Brasília. Available:

$<$ http://www.mpa.gov.br/index.php/imprensa/noticias/2226-consumo-de-pescado-no- brasilaumenta-237-em-dois-anos>. (accessed 09 June. 2014)

BUCKLEY, P. J.; PASS, C. L.; PRESCOTT, K. (1988) Measures of international competitiveness: a critical survey. Journal of Marketing Management, v. 4, n. 2, p. 175200

CÉSAR, A. D. S.; BATALHA, M. O. (2010) Analysis of the competitiveness drivers on the biodiesel productive chain: the case of castor bean. Production, v. 21, n. 3, p. 484-497.

COUTINHO, L. G.; FERRAZ, J. C. (2002) Estudo da competitividade da indústria brasileira. 4.ed. Campinas: Papirus, 510p.

MOON, H. C.; PEERY JR., N. S. (1995) Competitiveness of product, firm, industry, and nation in a global business. Competitiveness Review: An International Business Journal, v. 5, n. 1, p. 37-43.

CHIKÁN, A. (2008) National and firm competitiveness: a general research model.

Competitiveness Review: An International Business Journal, v. 18, p. 20-28.

CHUDNOVSKY, D.; PORTA, F. (1991) La competitividad internacional: principales cuestiones conceptuales y metodológicas. Universidad de la Republica. Uruguay. 
DOI: 10.14807/ijmp.v11i6.1033

Documentos de trabajo, 03/91. 85 p.. Available:

$<$ http://decon.edu.uy/publica/1991/Doc0391.pdf>. (accessed 26 January. 2000).

DUKE ENERGY (2013) A história da Duke Energy no rio Paranapanema. ABC da Energia, Available: <http://www.dukeenergy.com.br/Style\%20Library/ABCcaderno.pdf>. (accessed 09 June. 2014)

FARINA, E. M. M. Q. (1999) Competitividade e coordenação de sistemas agroindustriais: um ensaio conceitual. Revista Gestão e Produção, v. 6, n. 3, p. 147-161

GIULIANI, E. (2013) Network dynamics in regional clusters: evidence from Chile. Research Policy, v. 42, p. 1406-1419.

HARRISON, W. KENNEDY, P. (1997) A neoclassical economic and strategic management approach to evaluating global agribusiness competitiveness. Competitiveness Review, v. 7, n. 1 , p. 14-25.

HERCIU, M.; OGREAN, C. W. (2015) Competitiveness, and Intellectual Capital-Sources for Economic Development. Procedia Economics and Finance, v. 27, p. 556-566.

KUBITZA, F. (2015) Aquicultura no Brasil: Principais espécies, áreas de cultivo, rações, fatores limitantes e desafios. Panorama da Aquicultura, v. 25, n. 150, p. 10-23, jul./ago.

LATRUFFE, L.. (2010) Competitiveness, Productivity and Efficiency in the Agricultural and Agri-Food Sectors, OECD Food, Agriculture and Fisheries Papers, No. 30, OECD Publishing. Available: http://dx.doi.org/10.1787/5km91nkdt6d6-en. (accessed 10 Febreary 2012)

MAN, T. W .Y.; LAU, T.; CHAN, K. F. (2002) The competitiveness of small and medium enterprises: A conceptualization with focus on entrepreneurial competencies. Journal of Business Venturing, v. 17, n. 2, p. 123-142.

MARTIN, L.; WESTGREN, R.; VAN DUREN, E. (1991) Agribusiness competitiveness across national boundaries. American Journal of Agricultural Economics, v. 3, n. 5, p. 1456-1464.

ONO, E.; KUBITZA, F. (2003) Cultivo de peixes em tanques-rede. 3. ed. Jundiaí: Acqua Imagem, $112 \mathrm{p}$.

OSTRENSKY, A.; BORGHETTI, J. R.; SOTO, D. (2008) Aqüicultura no Brasil: o desafio é crescer. Secretaria Especial de Aqüicultura e Pesca: Brasilia.

PÉREZ-MORENO, S.; RODRÍGUEZ, B.; LUQUE, M. (2016) Assessing global competitiveness under multi-criteria perspective. Economic Modelling, n. 53, p. 398-408.

RANA, K. J.; HASAN, M. R. (2013) On-farm feeding and feed management practices for sustainable aquaculture production: an analysis of case studies from selected Asian and African countries. IN: HASAN, M. H.; NEW, M. B. (ed). On-farm feeding and feed management in aquaculture. FAO Fisheries and Aquaculture Technical Paper No. 583. Rome, FAO. 67 p. Available: https://www.cabdirect.org/cabdirect/abstract/20143141766 (accessed 10 May 2015)

SAMPAIO, F. G.; LOSEKANN, M. E.; LUIZ, A. J. B.; NEVES, M. C.; FRASCÁSCORVO. C. M. D.; RODRIGUES, G. S. (2013) Monitoramento e gestão ambiental da piscicultura em tanques-rede em reservatórios. Informe Agropecuário, Belo Horizonte, v. 34, n. 272, p. 1-11.

SAMPAIO, J. M. C.; BRAGA, L. G. T. (2006) Cultivo de tilápia em tanques-rede na Barragem do Ribeirão. Revista Brasileira de Saúde e Produção Animal, v. 6, n. 2. 
SANDOVAL JR, P. (coord.) (2013) Manual de criação de peixes em tanques-rede. 2. ed. Brasília: Codevasf, 68p.

SIDONIO, L. ; CAVALCANTI, I.; CAPANEMA, L.; MORCH, R.; MAGALHÃES, G.; LIMA, J.; BURNS, V.; ALVES JÚNIOR, A. J.; MUNGIOLI, R. (2012) Panorama da aquicultura no Brasil: desafios e oportunidades. BNDES Setorial - Agroindústria, n. 35, p. 421-463.

SILVA, C. A; BATALHA, M. O. (2000) Metodologia. In: SILVA, C. A; BATALHA, M. O. Estudo sobre a eficiência econômica e competitividade da cadeia da pecuária de corte no Brasil. Brasília: CNI-IEL/CNA/Sebrae, p. 17-28.

SIUDEK, T.; ZAWOJSKA, A. (2014) Competitiveness in the economic concepts, theories and empirical research. Acta Scientiarum Polonorum Oeconomia, v. 13, n. 1, p. 91-108.

VAN DUREN, E.; MARTIN, L.; WESTGREN, R. (1991) Assessing the competitiveness of Canada's agrifood industry. Canadian Journal of Agricultural Economics, v. 39, p. 727- 738.

WOOD JR, T.; CALDAS, M. P. (2007) Empresas brasileiras e o desafio da competitividade. Revista de Administração de Empresas, v. 47, n. 3, p. 1-13.

\section{APPENDIX A: SUPPLEMENTARY MATERIAL}

Table 1S: Questionnaire administered to tilapia fish farmers in São Paulo and Paraná, Brazil

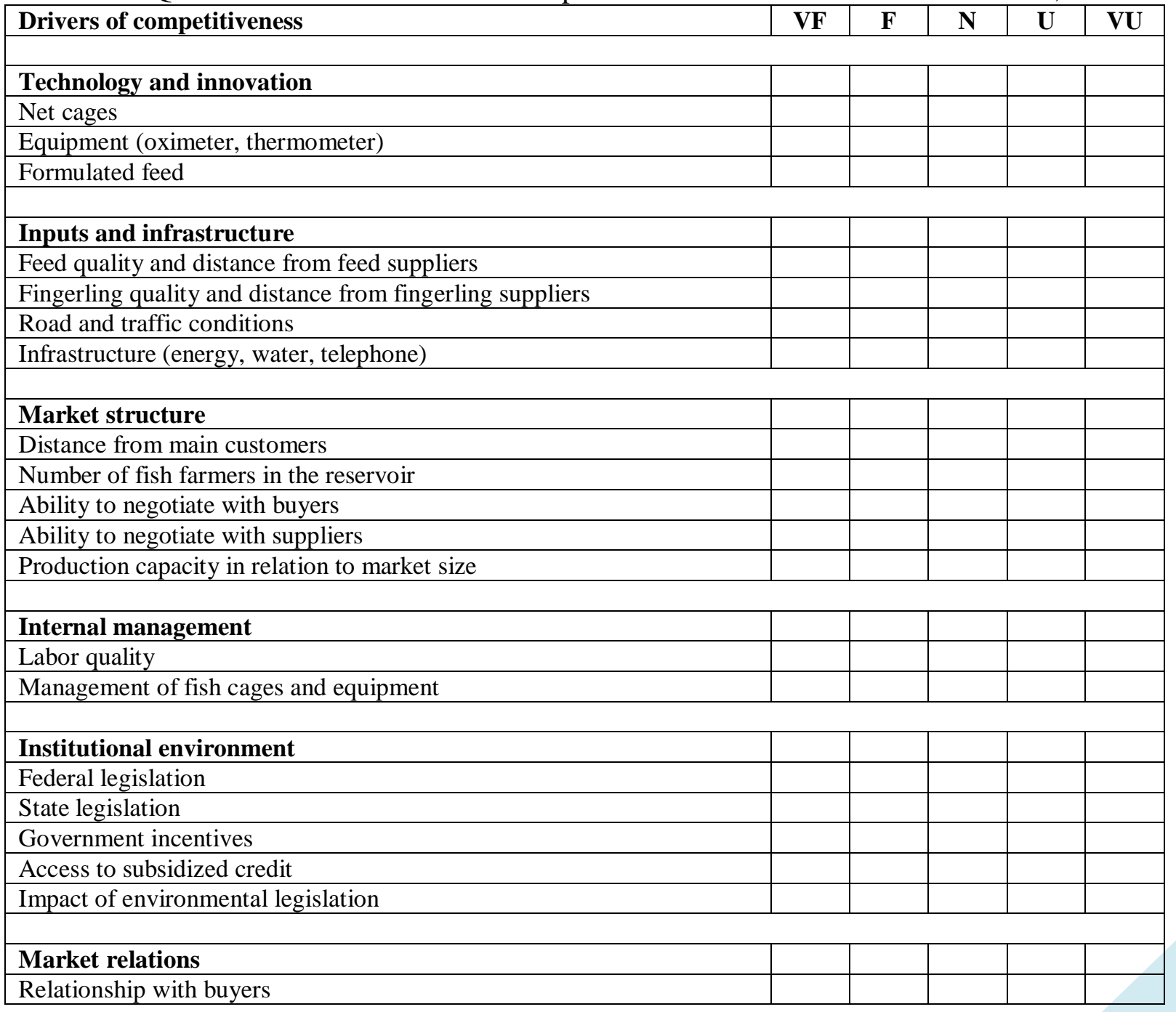


http://www.ijmp.jor.br

v. 11, n. 6, September - October 2020

ISSN: 2236-269X

DOI: 10.14807/ijmp.v11i6.1033

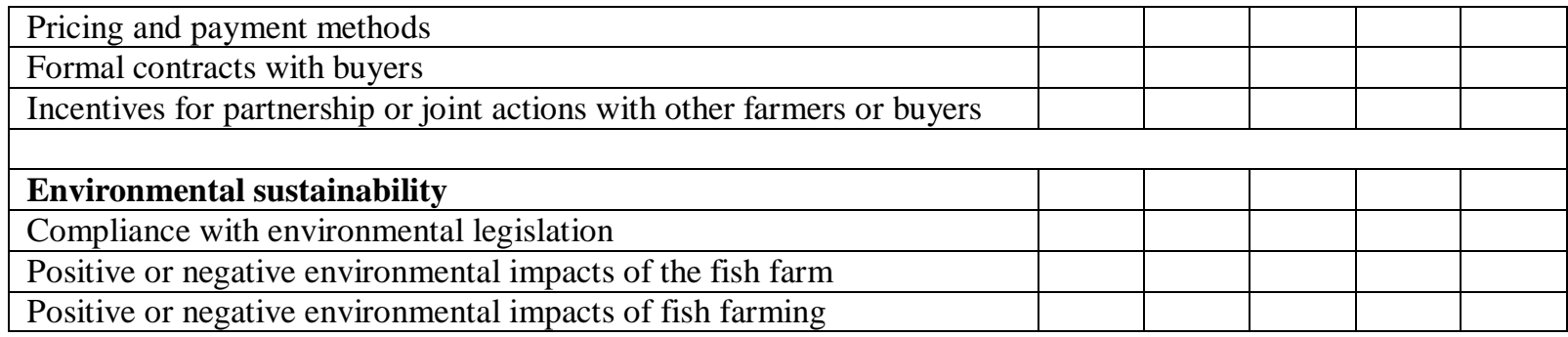

VF, very favorable; F, favorable; N, neutral; U, unfavorable; VU, very unfavorable 